\title{
TREKKING AND GEOTOURISM: A SYMBIOSIS IN CASE OF GOECHE LA TREK ROUTE OF WEST SIKKIM IN INDIA
}

\author{
Premangshu CHAKRABARTY* \\ Visva-Bharati University, Faculty of Geography, Department of Geography, \\ Santiniketan, Bolpur, West Bengal, India, e-mail: drpremangshuindia@gmail.com \\ Sanjoy Kumar SADHUKHAN \\ Visva-Bharati University, Department of Geography, \\ Santiniketan, Bolpur, West Bengal, India, e-mail: sks.geo86@gmail.com
}

\begin{abstract}
Citation: Chakrabarty, P., \& Sadhukhan, S.K. (2018). TREKKING AND GEOTOURISM: A SYMBIOSIS IN CASE OF GOECHE LA TREK ROUTE OF WEST SIKKIM IN INDIA. GeoJournal of Tourism and Geosites, 23(3), 848-860. https://doi.org/10.30892/gtg.23319-333

Abstract: With the aim to analyse how trekking and geotourism advances hand in hand, Goeche La trek route of Sikkim in Kanchenzongha National Park is selected for the present study. In order to understand the terrain realities, the application of the tools available in geoinformatics is made along with prolonged participant observation as trekkers in the field. Carrying capacity appears as a problem from increasing trekking activities particularly after the recognisition of the park as a world heritage site in the year 2016. This paper is an attempt to interprete the scope of diversification of its trekking activities from sustainability perspective.
\end{abstract}

Key words: Trekker, Terrain, Carrying Capacity, Heritage, Sustainablity

\section{INTRODUCTION}

Trekking is nature sensitive in the sense that enjoying nature is most important motivation for the trekkers. Increase of trekking in any area leads to economic growth which is related to increases of income level and employment opportunities. Infrastructural growth and improvement in standard of living are also related to such development. Trekking status of an area depends on 5As i.e. status of attraction, accommodation, accessibility, amenities and administration. Trekking in high altitude is classified as one of the branches of adventure tourism since trekkers have to bear enormous risk during trek. One of the main features of contemporary tourism is the increasing segmentation of the demand, in terms of income, age, consumptions, habits, origin of the flows, educational levels, motivations, attitudes (Cappucci et al., 2015). With the development of geotourism, geosites and geomorphosites are among the important elements to enjoy, when people walk, hike or climb mountains (Serrano et al., 2011). It is a unique form of adventure tourism where travelers are ready to accept the limited

\footnotetext{
* Corresponding author
} 
infrastructure or totally undeveloped destination where they get the authentic experience on biodiversity aspects during walking in the nature. Geotourism has been documented as one of the strategies to support biodiversity conservation (Hakim, 2017). With such an integrated educative approach of combining biological and geological aspects, visitors may be motivated during trek to interact with the natural system and environment heritage (Forleo, 2017). For the trekkers, the mountainous countries could offer the natural beauties of mountain peaks, biodiversities of mountainous forests and the distinguishing geosites on the way. To ensure sustainable trekking, identification and characterization of geosites are however very much important, especially while planning an educational trail (Strba, 2015). It is vital to maintain simultaneously the landscape and cultural values (Marszalek, 2018).

Physical parameters such as slope, distance, elevation of trekking track, standard of trekking time and climatic condition of trekking corridor are closely related to trekkers' performances and satisfaction. For the convenience of the geotourisity, who are sensitive to earth and environmental dynamics, geology and geomorphology of the terrain could be presented in a simple and educational way so that knowledge on geoheritage conservation may impart to a wider audience at the same time (Miccadei, 2014). Walking time is vital for the trekkers to complete the whole trek from origin place to destination place and also returning back to origin place which should be preplanned before initiation a trek to provide sufficient scope to enjoy geosites. The relation between walking time and walking speed varies from segment to segment of the route depending on slope character and elevation of the mountain region. Another relevant issue is the carrying capacity for which data is required to confirm the trend in a continuum, the opposite ends of which are constitute by ecotourism and mass tourism (Cavuta, 2016).

A number of studies have been conducted worldwide on relation between trekking and mountain environment with application of the tools of geoinformatics. One of such study by Nepal and Nepal (2004) on Sagarmatha National Park is exemplary in relation to analysis on trail use intensity. For the vegetation characteristics of the study area in particular, i.e. Kanchenzongha Biosphere Reserve (KBR) with special reference to Yuksam-Dzonri- Goeche La trekking route, the contribution of Subba et al., (2016) is very much noteworthy. The study on Yuksam-Dzonri trekking corridor on habitat change by Chettri et al., (2005) represents the scenario of forest depletion in relation to decreasing bird diversity in the region. In the analysis, Singh et al., (2003) pointed out the increasing vulnerability of Rhododendron in the high altitude trekking corridor of Sikkim Himalaya. Controls on grazing and human interference have been identified as the remedies. Collection of firewood for coocking and heating purposes along the trek route has been previously identified as the root cause of forest depletion in the trekking corridor by Chetri et al., (2001) while Rai et al., (1998) already highlighted trail sight erosion as a result of trampling by trekkers and grazing activities of animals. While walking on human interference in the ecologically fragile areas, Kumari et al., (2010) introduced site specific criteria, which are useful in the study of environmental impacts on the trekking route concerned. Examination of available literatures reveals a research gap on application scope of geotourism and geoconservation in the trekking corridor in relation to present status of forest depletion and biodiversity loss. The broad objectives of the study undertaken are as follows:

i. To evaluate the physical and topographical characteristics of trekking route from geotourism perspectives.

ii. To enumerate of depletion of forest along the trek route with a view to its impacts on geosites and geomorphosites.

iii. To examine the overall sustainability status of trekkers activities in relation to existing geo-conservation strategies. 


\section{SELECTION OF THE STUDY AREA}

Yuksam to Goeche La trekking corridor of West Sikkim District (Figure 1) is situated in the Kanchenzongha National Park (KNP), which is famous for its rich biodiversity and designated as Kanchenzongha Biosphere Reserve (KBR). The total length of this trekking route from Yuksam to Goeche La (via Dzonri view point) is about $44 \mathrm{Km}$. It is administratively under the jurisdiction of West Sikkim District of a tiny north eastern state of India called Sikkim. As a hilly district situated in the western side of a Himalayan state, West Sikkim is famous as a trekkers' paradise. Latitudinal and longitudinal extension of West Sikkim District is $27^{\circ} \mathrm{Oo}$ ' $\mathrm{N}$ to $27^{\circ} 45^{\prime} \mathrm{N}$ and $88^{\circ} \mathrm{OO}$ ' E to $88^{\circ} 24^{\prime}$ E Sharing international border in the west with Nepal,worldwide famous for trekking activities. In West Sikkim, Yuksam, Uttaray and Hiley are serving as the gateway of respective trekking corridors.

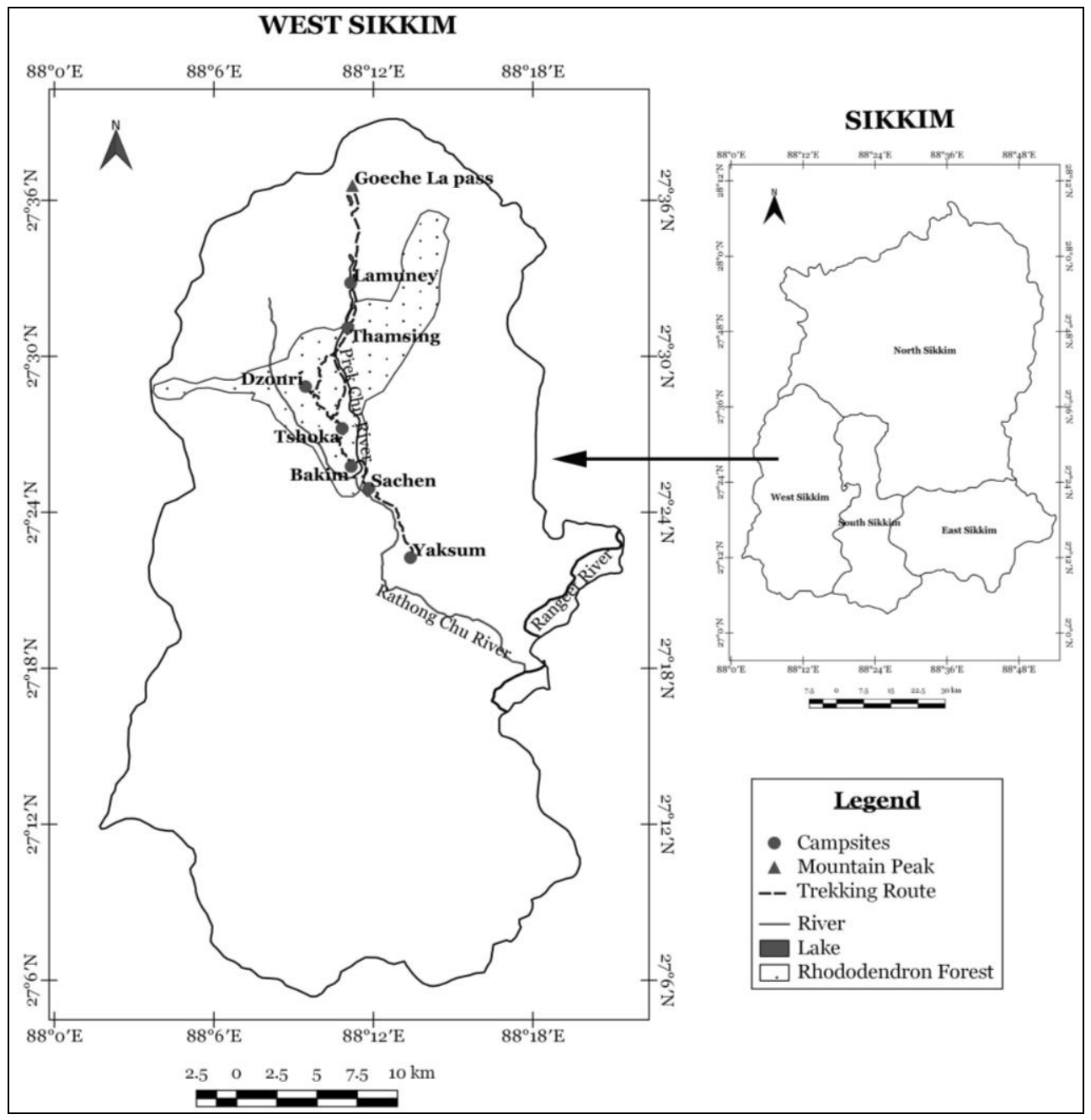

Figure 1. Location map of the study area

Yuksam is the initiation point of Yuksam to Goeche La trekking corridor which is about $150 \mathrm{Km}$. by road from NJP railway station of West Bengal. Yuksam is a small village which has historical signification. Yuksam was the capital of the first king of 
Sikkim named Phutsoh Namgyal, also called Chogyal. The Katok Lake and Kaecheoplari Lake are the two holy lakes of Buddhists situated at Yuksam. Apart from lake, there are some old monasteries among which Dubdi monastery is the oldest monastery located of one hour walking distance from Yuksam (Rubita, 2012). The Goeche La trek route passes through the Kanchenzongha National Park and such trek is a package of eight days as elaborated in the itinerary (Table 1) mentioning the first six days to reach Goeche La, While return journey takes about two days.

Table 1. Segments of Trek Route to Goeche La (Data source: Field survey during trek, November,2017)

\begin{tabular}{|c|c|c|c|c|l|}
\hline Day & $\begin{array}{c}\text { Camp } \\
\text { Sites }\end{array}$ & $\begin{array}{c}\text { Altitude in } \\
\text { Metres }\end{array}$ & $\begin{array}{c}\text { Distance } \\
\text { in Km. }\end{array}$ & $\begin{array}{c}\text { Intermediate } \\
\text { Halt Station }\end{array}$ & \multicolumn{1}{|c|}{ Trekkers' Attraction } \\
\hline 1 & Yaksum & 1780 & 0 & x & Lake, Monasteries \\
\hline 2 & Sachen & 2321 & 10 & X & Forest \\
\hline 3 & Tshoka & 3566 & 9 & Bakim & Cave \\
\hline 4 & Dzonri & 4007 & 6 & $\begin{array}{c}\text { Phedang, Deorali } \\
\text { Top }\end{array}$ & $\begin{array}{l}\text { Rhododendron Forest, } \\
\text { Mountain Peaks }\end{array}$ \\
\hline 5 & Thansing & 3939 & 8 & Kockchurang & Mountain Peak view, River side trek \\
\hline 6 & Lamuney & 4184 & 4 & x & Mountain peak view \\
\hline
\end{tabular}

Kanchenzongha National Park is the main attraction of the trekking route, which extended from Lanhok valley. It is a cold desert to the ridges of Lachen in the North district of Sikkim. The western boundary of the park is international boundary sharing with Nepal and China. The total area of the park is 1784 sq. km, which absorb about $25.14 \%$ of total geographical area of Sikkim state. Only $18.32 \%$ area of the park is however situated in West Sikkim (Bhattacharya \& Kumari, 2010). The exposure of garnetiferousbanded biotite gneiss or augen gneiss in this landslide prone area is representative of its geoheritage for the geotourists. Various types of Rhododendron species changing with altitudinal variations may attract the attention of the visitors. Rich biodiversities, panoramic view of mountains and valleys, holy lakes and monasteries, waterfalls, flower blooms, migrant birds and wild animals are drawing huge number of trekkers in this region which ari the carrying capacity issues simultaneously.

\section{MATERIALS AND METHODS}

The morphology developed on lithological formations have immense geotourism potentials (Gavrila, 2011; Gozner, 2014). The followings are among the most representative elements of topography in terms of geotourism at Goeche La trekking corridor:

1. Moraine (typological classification, characteristics, micro landforms attracting the trekkers)

2. Glacier Lake ( Samiti Lake: formation hydrology, morphology, function)

3. Morphological features of river Prek Chu- Waterfall near Sachen, Cascade on the way of Kockchurang to Thansing.

4. Cold Desert topography beyond Goeche La pass drawing the geotourist.

The moraines are Quarternary deposits, the tentative age of which is ranging from recent to subrecent (Luitel et al., 2012). Geologically being a part of the lesser Himalayas the area is basically composed of Darjeeling gneiss of pre-cambrian origin (Geological Survey of India, 2012). Collapse of the glacio fluvial material particularly during the retreat of Onglaktang glacier resulted an outstanding geotourism landscape (Figure 2) near the camping ground at Thansing (Figure 3) which is next halt stations of Goeche La trek after Dzonri. Widespread rubbles and boulders strewn over a wide area down the valley attracts the attention of trekkers (Chattopadhyay, 2008). Such landscapes are 
subjects of interpretation by glacial geomorphologists to serve the purpose of educative tourism, which is one of the objectives of geotourism promotion. Glacial lakes in higher altitude containing water are formed by melt water discharge from ice being accumulated in depressions (Figure 4) bounded by geomorphic features like terminal moraines.

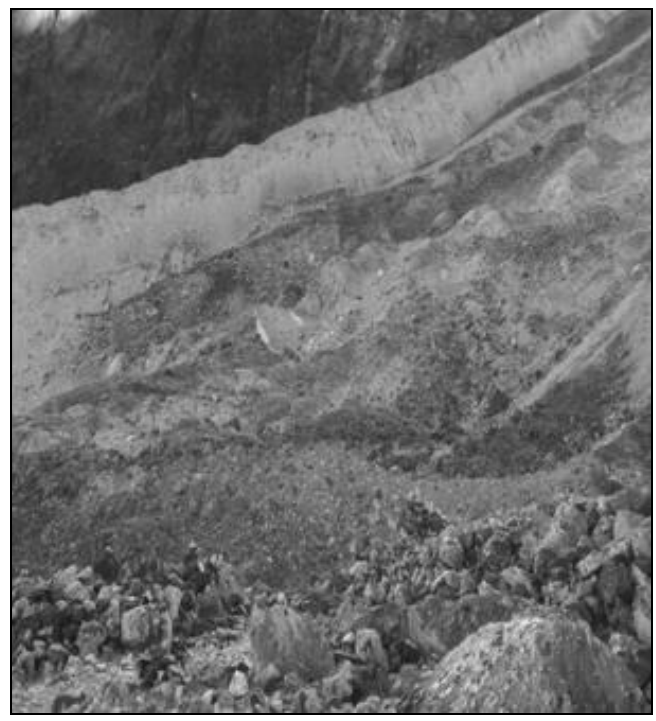

Figure 2. A Moraine Landscape

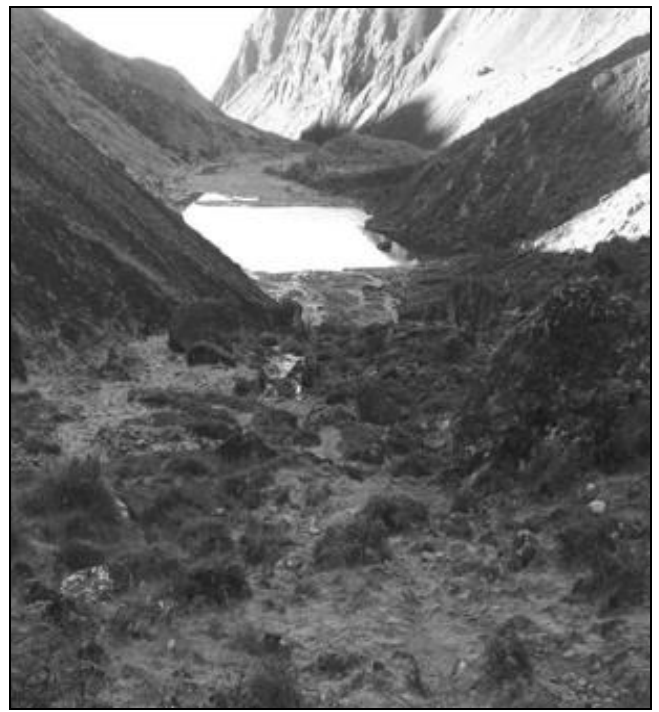

Figure 4. Glacial Lake named Samiti

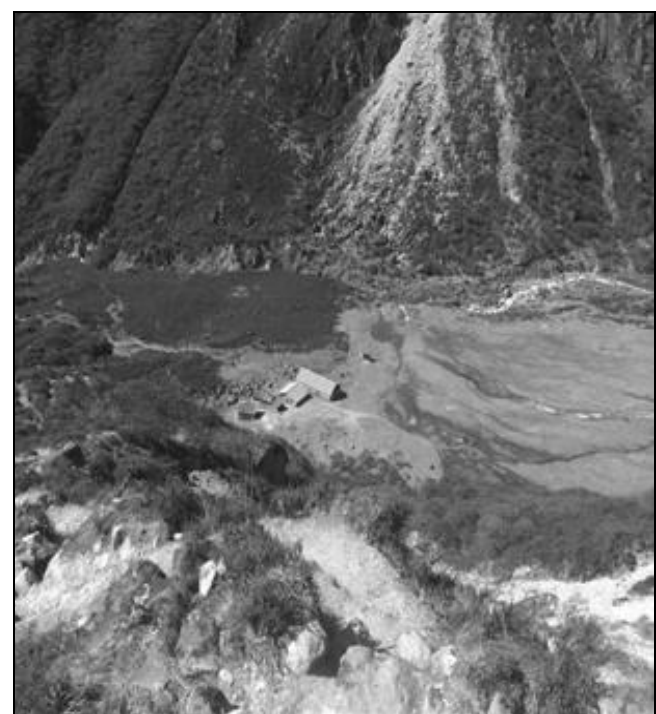

Figure 3. Campsite at Thangsing

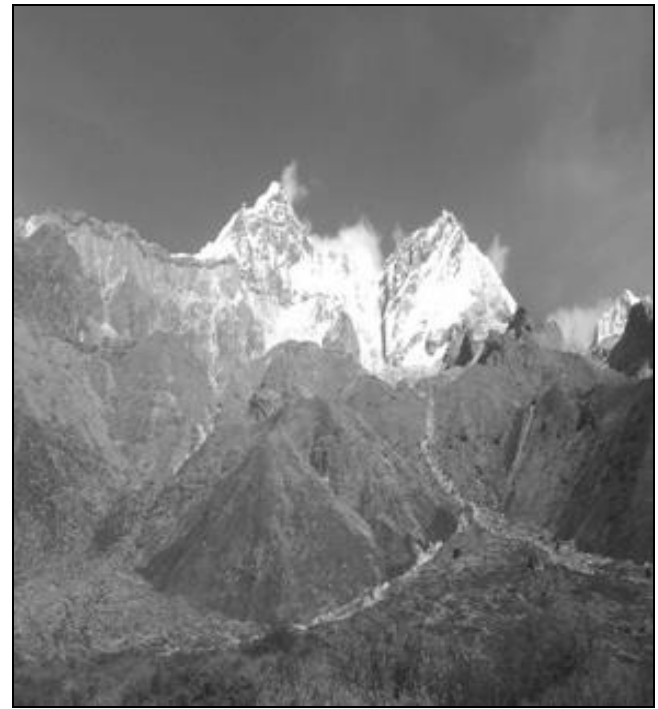

Figure 5. Topography as Gotourism Motivation

On the trek route, the lakes with no water in dry season are also found on scree and hillwash material deposit areas. The complex folded structure and varied lithology with exposure of older rocks compose the topography (Figure 5) of the region (Geological Survey of India, 2012). The waterfalls (Figure 6) and cascades (Figure 7) observed on the way are among the prominent evidences of tectonic activities characteristically frequent 
in the region. Geomorphosites developed by the action of river Prek Chu (Figure 8) are the most regular object of photography as revealed from the analysis of photographs captured by the sampled trekkers in Goeche La trek route. The route passes through U-shaped glacial valley from Thansing (Figure 9), which is an outstanding experience for a geotourists. Prolonged engagement in the field is supplemented by persistent observation in credibility context to obtain the data on the impact of trekking on natural environment with special emphasis to geomorphosites. Triangulation is applied at source as well as on methods for the present study which relies both on primary and secondary data. Revisit to the field objects is applied as the method to achieve conformability, essential for reducing the extant of biases (Baxter et al., 1997).

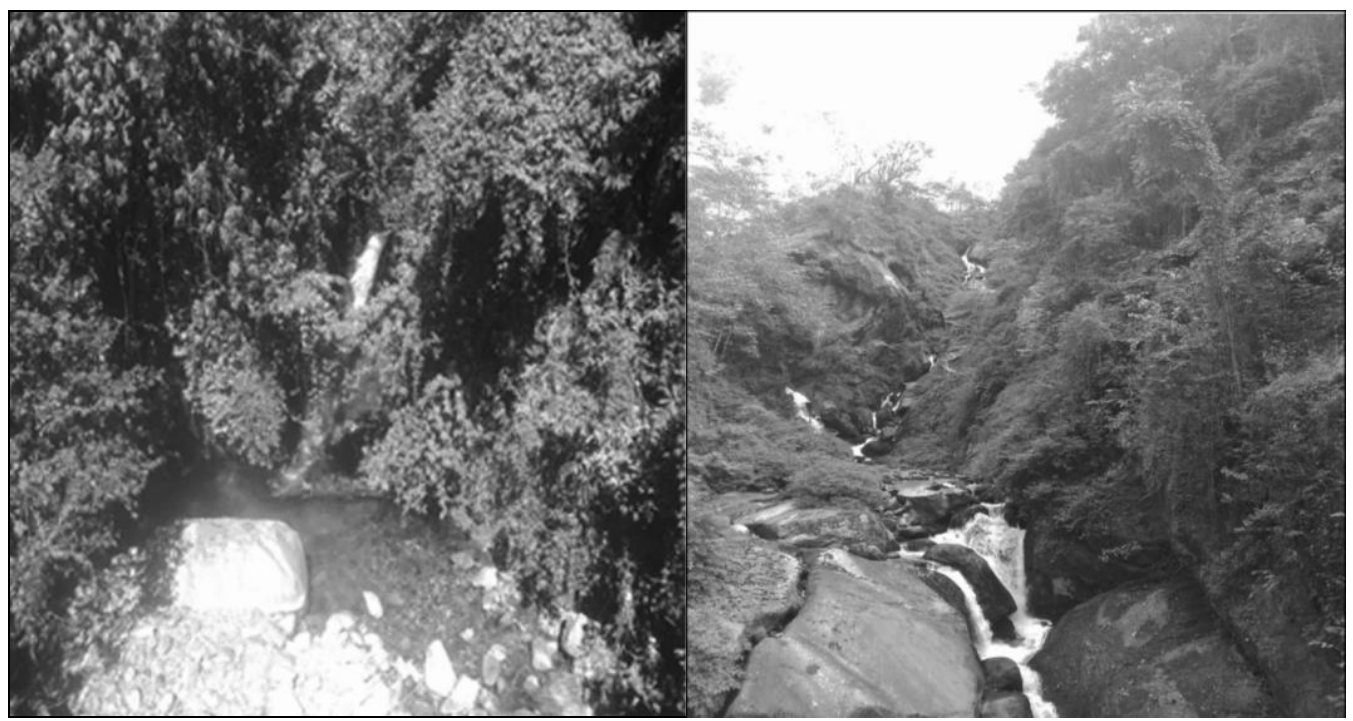

Figure 6. Spectacular Waterfall

Figure 7. Amazing Cascade

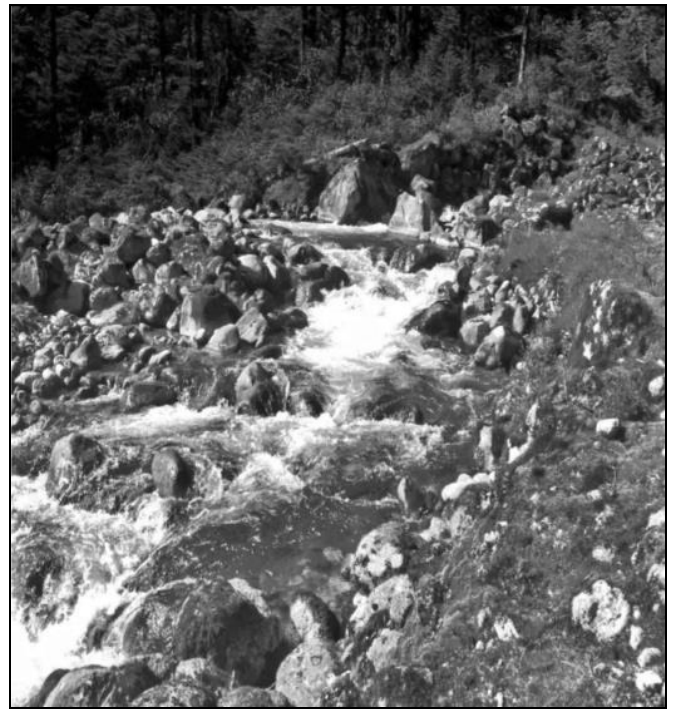

Figure 8. Riverine Geomorphosites

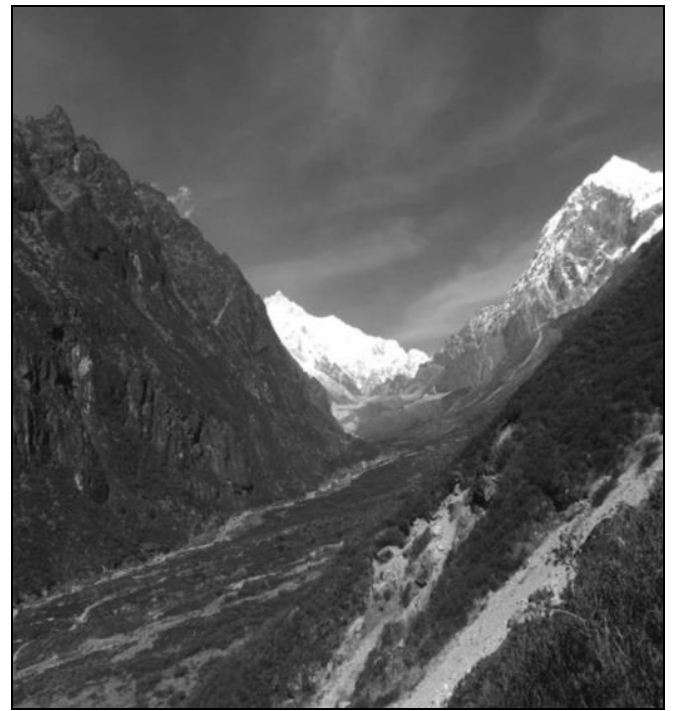

Figure 9. Typical Glacial Valley 
The satellite images of the area have been procured from USGS Earth Explorer site. A number of layers have been generated by using district planning map, tourist map of Sikkim etc by the process of vectorization using QGIS software. The Digital Elevation Model (DEM) from Yuksam to Goeche La trekking route of West Sikkim district is created with 1:100000 scale. Data updation is completed by field survey using GPS Essential software of android mobile version application. Path analysis by using Google Earth software is applied to obtain DEM data in KML format. After generating DEM, the satellite images of band IV and V of LANDSAT-8 have been downloaded from USGS Earth Explorer. The equation of NDVI which is used in raster calculator is (Band V Band -IV)/(Band-V+ Band IV). By using QGIS software, slope map and elevation maps have been prepared with the help of DEM data and raster analyze tool. The total length and average slope of trekking route, direction of slope, elevation of start and end point, highest point of the trekking route also have been enumerated using QGIS software by using Profile tool (Table 2). The relation between speed and walking time is found varying on the basis of the steepness of slope of the trekking route.

Table 2. Segment wise topographical character of the trail

(Data source: Image Analysis and GPS Survey undertaken during Field Work, 2017)

\begin{tabular}{|c|c|c|c|c|}
\hline Trekking Segment & $\begin{array}{c}\text { Track } \\
\text { Length (km) }\end{array}$ & $\begin{array}{c}\text { Starting } \\
\text { Elevation (m) }\end{array}$ & $\begin{array}{c}\text { Ending } \\
\text { Elevation (m) }\end{array}$ & $\begin{array}{c}\text { Maximum } \\
\text { Elevation (m) }\end{array}$ \\
\hline Yaksum to Sachen & 10 & 1780.37 & 2321.65 & 2321.65 \\
\hline Sachen to Tshoka & 9 & 2321.65 & 3544.13 & 3566.13 \\
\hline Tshoka to Dzonri & 6 & 3544.13 & 4007.62 & 4043.65 \\
\hline Dzonri to Thansing & 8 & 4007.62 & 3939.03 & 4104.44 \\
\hline Thansing to Lamuney & 4 & 3939.03 & 4184.80 & 4188.26 \\
\hline Lamuney to Goeche La & 7 & 4184.80 & 4961.83 & 5002.66 \\
\hline
\end{tabular}

Questionnaires have been prepared which consisting direct and open ended questions to conduct the ethnographic surveys. Adventure tourism associates (like guides, yak operators, cook and porters), hotel and lodges operators and shopkeepers selling tea and other beverages were among the sampled respondents in the survey. Trekkers' survey and local people survey have also been conducted using structured questionnaire (Thomas, 2016). The participant observation method is undertaken by opting trekking opportunities from Yaksum to Goeche La with different group of trekkers before monsoon and after monsoon. Secondary data have been collected from different reports of publications. Data on trekkers have been derived from Yuksam Police Station as well as from some sampled hotels. A number of associations of trekkers have been consulted for triangulation of information derived from field and also for cross verification purpose. The nature of the whole work is empirical and ethnographic combining quantitative and qualitative methods.

\section{RESULTS DISCUSSIONS}

Trekkers' arrival rate in Yuksam to Goeche La trekking corridor in West Sikkim is increasing rapidly. Near about two thousand domestic and foreign trekkers visit the area in every month of trekking season in post monsoon period from mid October to December and pre monsoon during March to mid of June. Adventure lovers arrive Yuksam for trekking and experiencing simultaneously the beauties of nature and geomorphosites. Kanchenzongha National Park is already designated as a Biosphere Reserve in this region, which bears unique natural and cultural significance. Based on the elevation and topographic characteristics, the plant community of Kanchenzongha 
National Park can be broadly categorized into wet temperate broad leaved forest, temperate conifer forest, sub-alpine forest, alpine scrub and alpine meadows (Subba et al., 2016). Climatic variation and different topographical landscape characteristics provide a diversity of Rhododendron species.

Annually the trekking corridor has to bear the activities of about 2000 travelers (from minimum 2 to maximum 16 per trekking group) and average 500 trainees of Himalayan Mountaineering Institute from Darjeeling. They are accompanied by nearly 300 supporting staff (including porters, cooks and guides depending on number of trekkers in each groups) in the trekking season generating enormous impact on mountain environment. The maximum impact is however generated from the movement of about 140 dozen yak per year along with horses. A sustainable plan is needed for preservation of nature in the region to minimize the adverse effect of trekking activities. Goeche La is specifically famous for trekkers because:

a. Various mountain peaks of Eastern Himalaya e.g. Kanchenzongha $(8586 \mathrm{~m})$, Rathong (7349m), Kabaru (7353m), Pandim (6691m) and Jupano (5650m) are visible.

b. The beauty of Samiti lake which is the source of Prek Chu river.

c. Various types of Rhododendron species.

d. Migratory birds and animal view during trek.

Kanchenzongha National Park has been notified as a biosphere reserve in the year 2000 by Indian Ministry of Environment and Forest. It has an area of $2129 \mathrm{sq} . \mathrm{km}$ with altitudinal variation from Yuksam (1780m) to Mt. Kanchenzongha $(8586 \mathrm{~m})$. The national park also listed in IUCN list as II type category of biosphere reserve (Dam, 2013). The slope of this area ranges from moderate to steep which make the route vulnerable to landslides depending on lithology and characteristics of the slope facets to be trekked to reach Goeche La pass (Figure 10). The table 3 represents the major landslides detected on various segments during the field work.

Table 3. Detection of Landslides along the Trek Route (Data source: Field Survey, Nov, 2017)

\begin{tabular}{|c|c|c|}
\hline $\begin{array}{c}\text { Trekking } \\
\text { Segments }\end{array}$ & $\begin{array}{c}\text { Number of } \\
\text { Landslides }\end{array}$ & \multicolumn{1}{c|}{ Remarks } \\
\hline Yaksum to Sachen & o & $\begin{array}{l}\text { Low elevation zone, a stretch of 10 km., covered at an average } \\
\text { speed of 2km./hr. }\end{array}$ \\
\hline Sachen to Tshoka & 3 & $\begin{array}{l}\text { This is transition of two hills between which Prek Chu river } \\
\text { flows. Landslides are found on the slope descending to } \\
\text { riverbed. No such slide on rising slope crossing the river is } \\
\text { found due to gentle gradient of waning slope. }\end{array}$ \\
\hline Tshoka to Dzonri & 2 & $\begin{array}{l}\text { This is a zone of rectilinear slope and major landslides are on } \\
\text { the trekking route itself bringing hazard for the trekkers }\end{array}$ \\
\hline Dzonri to Thansing & 1 & $\begin{array}{l}\text { This is a downhill segment where the only significant } \\
\text { landslide is found generated due to making way for the } \\
\text { trekkers and particularly the Yaks accompanying them. }\end{array}$ \\
\hline Thansing to Lamuney & $\mathrm{O}$ & $\begin{array}{l}\text { Permanently frozen ground and the lithology of the area being } \\
\text { responsible for no major landslide in this stretch. }\end{array}$ \\
\hline Lamuney to Goeche La & $\mathrm{O}$ & \begin{tabular}{l} 
Waxing slope of higher altitude which is much more stable. \\
\hline
\end{tabular} \\
\hline
\end{tabular}

Infrastructure and superstructure provided in Goeche La trek route is still at its juvenile stage. Trekkers have to be well-equiped with information generating instruments by their own because there is no intermediate provision to convey them on weather condition, vulnerability situation of slide prone areas or any other matters relevant to their requirements (Priskin, 2001). The elevation profile (Figure 11) of the trekking trail further reveals why most of the trekkers are compelled to back from 
midway of trekking. This particular trek demands extreme body fitness of the trekkers. Initially the whole trekking programme from Yuksam to Goeche La and return to Yuksam requires eight days. After two days the trekkers reach above 3000m elevation zone and face difficulties due to paucity of oxygen and adverse weather condition.

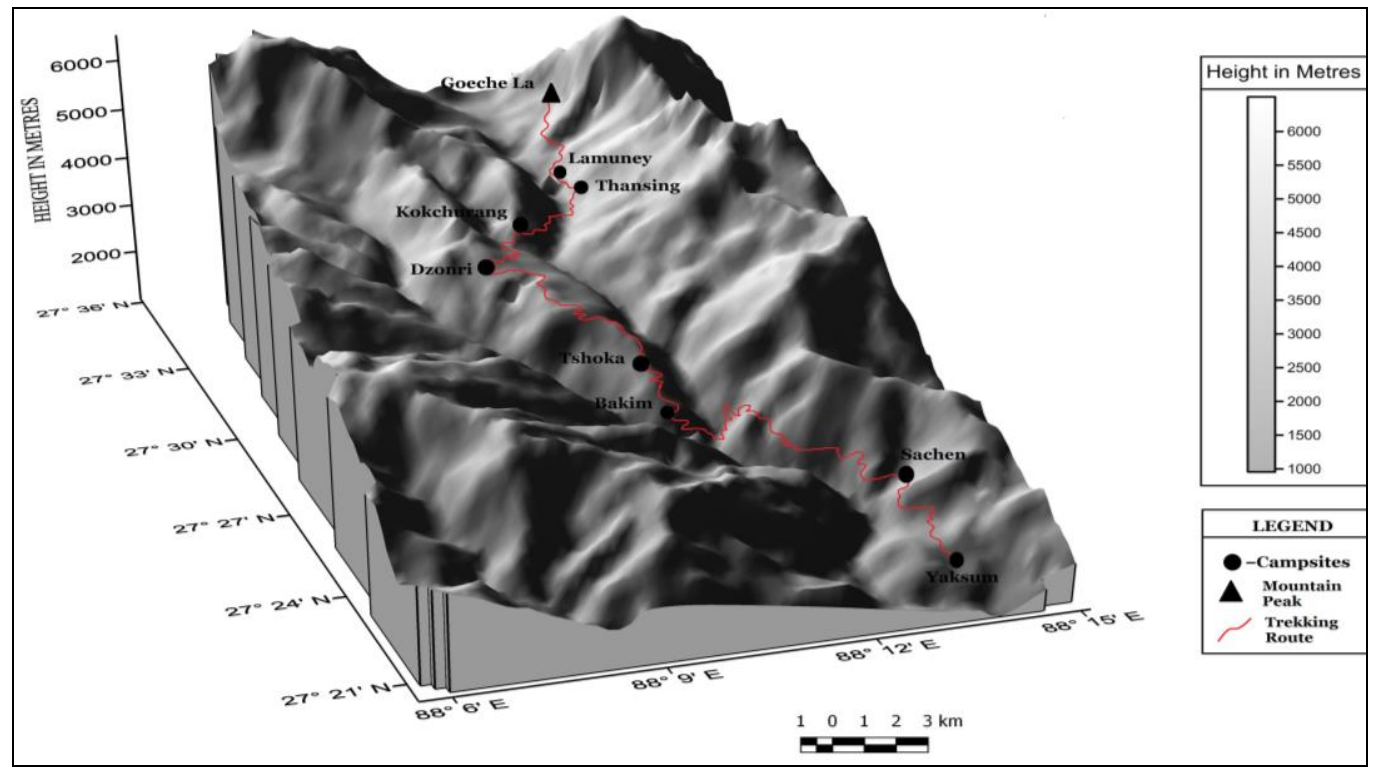

Figure 1o. Digital Elevation Model representing terrain characteristics

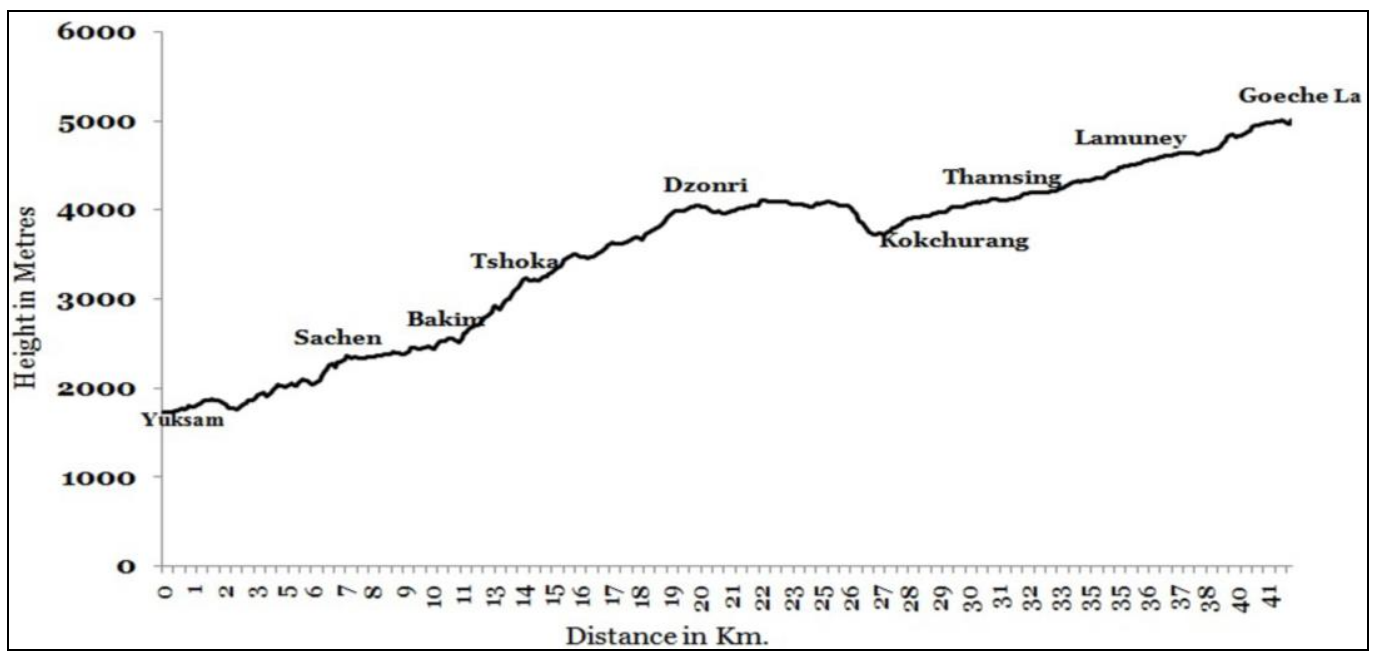

Figure 11. Elevation profile along the trek route from Yuksam to Goeche La

Trekking time also differ along this trekking corridor segment to segment due to the variation of slope and elevation of different segments of the trek (Table 4). Trekking segment of day-3 from Tshoka to Dzonri and day-6 from Lamuney to Goeche La are reported as more difficult segment of entire trekking schedule. Day -4 from Dzonri to Thansing and Day-7 from Kockchurang to Bakim are identified by trekkers as 
moderately difficult in the whole trekking route. The trekking corridor has several campsite and location offering the exprience of amazing geosites and geomorphosites (Table 4). Each and every of such sites are none but the geotourism paradise.

Campsite infrastructure is not presently enough to earn trekkers' satisfaction. Lack of waste management planning in campsite not only pollutes environment but also arising health hazards. The trekking corridor is transferred into nearly a garbage bin. Geotourists are interested primarily in natural areas endowed with geomorphosites depending on factors like sensitivity,adapting ability and feedback capacity in the individual level (Irimus et al., 2011). So maintenance of environment around campsite is very important both for trekkers and geotourists. Five indicators were used to derive the satisfaction level of the trekking group surveyed on the campsite accommodation by using Likert 11 point scale (Table 5).

Table 4. Trekking speed as representative of terrain difficulties (Data source: Participant Observation, 2017)

\begin{tabular}{|c|c|c|c|c|}
\hline Day & Segment & $\begin{array}{c}\text { Major geosites } \\
\text { and geomorphosites } \\
\text { on trek route }\end{array}$ & $\begin{array}{l}\text { Trekking } \\
\text { speed/ } \\
\text { Day }\end{array}$ & Remarks \\
\hline 1 & $\begin{array}{l}\text { Yuksam to } \\
\text { Sachen }\end{array}$ & Low height waterfalls & 10 & $\begin{array}{l}\text { Generally } 6 \text { hours trekking. Slope ranging } \\
\text { lies between from } 10^{\circ} \text { to } 20^{\circ} \text {. }\end{array}$ \\
\hline 2 & $\begin{array}{l}\text { Sachen to } \\
\text { Tshoka }\end{array}$ & Waterfall, landslides & 9 & $\begin{array}{l}\text { Easy trek upto Bakim. After Bakim slope } \\
\text { gradually increases upto } 30^{\circ} \text {. }\end{array}$ \\
\hline 3 & $\begin{array}{l}\text { Tshoka to } \\
\text { Dzonri }\end{array}$ & \begin{tabular}{c|} 
Glacial lakes, \\
conspicuous landslides
\end{tabular} & 6 & $\begin{array}{l}\text { Moderate to difficult trek. Generally it takes } 8 \\
\text { to } 9 \text { hours. Ascent of slope upto above } 45^{\circ} \text {. }\end{array}$ \\
\hline 4 & $\begin{array}{l}\text { Dzonri to } \\
\text { Thansing }\end{array}$ & $\begin{array}{l}\text { Mountain peaks, } \\
\text { Exposed rocks. }\end{array}$ & 8 & $\begin{array}{l}\text { Moderate trek. It takes } 7 \text { hours with a } \\
\text { decent mostly through scarp slope }\end{array}$ \\
\hline 5 & $\begin{array}{l}\text { Thansing to } \\
\text { Lamuney }\end{array}$ & $\begin{array}{l}\text { Sculptures made by } \\
\text { Prek Chu river }\end{array}$ & 4 & $\begin{array}{l}\text { Trekkers' starting trek after lunch. Easy } \\
\text { trek. Slope is below } 20^{\circ} \text {. }\end{array}$ \\
\hline 6 & $\begin{array}{l}\text { Lamuney to } \\
\text { Goeche La }\end{array}$ & $\begin{array}{l}\text { Glacial lake,moraine } \\
\text { mountain peaks, and } \\
\text { cold desert }\end{array}$ & 7 & $\begin{array}{l}\text { Starting trek from camp at around } 3.00 \text { a.m. } \\
\text { for watching sunrise view at Goeche La pass } \\
\text { and returning back. Ascent of slope upto } 40^{\circ} \text {. }\end{array}$ \\
\hline
\end{tabular}

Table 5. Trekkers' satisfaction survey outcomes (N=41) (Data source: Field Survey, 2017-2018)

\begin{tabular}{|l|c|c|c|c|c|c|c|c|c|c|c|}
\hline \multirow{2}{*}{ Indicators } & \multicolumn{10}{|c|}{ Level of Satifaction } \\
\cline { 2 - 14 } & $\mathbf{- 5}$ & $\mathbf{- 4}$ & $\mathbf{- 3}$ & $\mathbf{- 2}$ & $\mathbf{- 1}$ & $\mathbf{0}$ & $\mathbf{+ 1}$ & $\mathbf{+ 2}$ & $\mathbf{+ 3}$ & $\mathbf{+ 4}$ & $\mathbf{+ 5}$ \\
\hline Overall accommodation status of Trekkers Hut & & & 4 & 9 & 6 & 12 & 5 & 2 & 3 & & \\
\hline Quality of furniture provided with & & & 14 & 11 & 7 & 8 & 1 & & & & \\
\hline Drinking Water & & & & & & 15 & 16 & 5 & 4 & 1 & \\
\hline Cooking Provision & & & & & 11 & 20 & 5 & 6 & & & \\
\hline Quality of Latrine & & & 10 & 5 & 11 & 11 & 4 & & & & \\
\hline
\end{tabular}

The influx of trekkers built up pressure on the rhododendron species (Chettri et al., 2005). Presence of components like polyphenols and flavonoids in the rhododendron wood are fireprone and thereby readily utilized by the trekkers for cooking and heating the camp. Out of 36 species of rhododendron 8 species are already declared endangered for the demand of firewood and trekking road construction (Singh et al., 2014). NDVI analysis of the trekking corridor reveals that density of forest considerably decreases in between 2014 and 2018. In Figure 12, an overlay is made to represent the change of land cover which is alarming indeed. Field investigation reveals the role of Yaks specifically for the forest depletion along the trek route. 
In different terrains, the impact of grazing is more as the animals get more time to consume vegetation on their way. Highest species diversity is noticed between 3000 metres to 4000 metres which is extended from Tshoka to Dzonri trekking segment. The species availability decreases from above 4500 and 2500 metres downwards (Singh et al., 2003). A number of other factors are also found responsible for the depletion of forest in Yuksam -Goeche La trekking corridor including climate change and various anthropogenic activities (Singh et al., 2014).

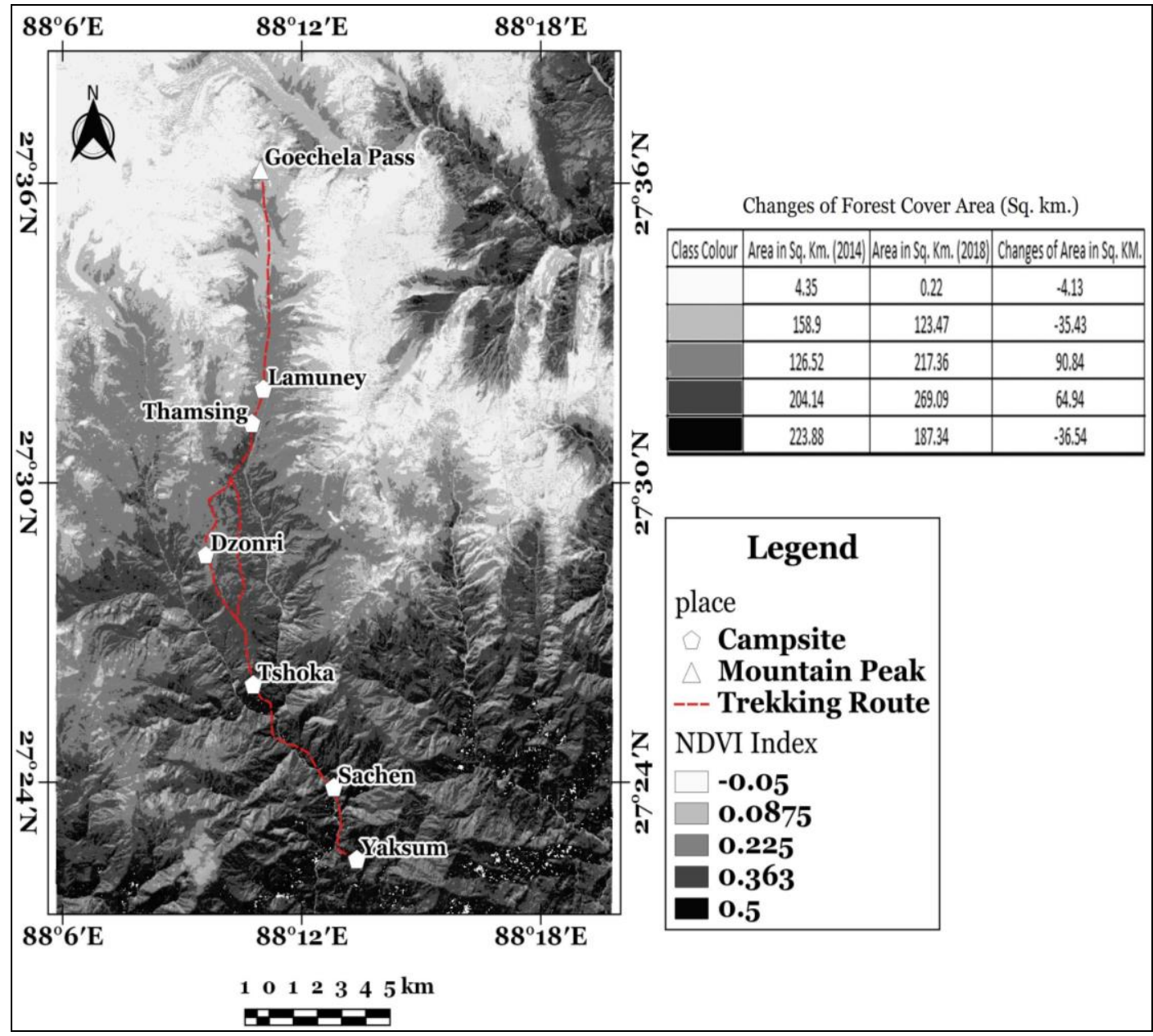

Figure 12. Overlay result of NDVI maps

\section{CONCLUSION}

From the symbiosis of trekking and geotourism at Goeche La, urgent need for geoconservation planning arises.Carrying capacity assessment is needed to enumerate the stress on environment for the increasing of trekking activities. Sustainable trekking development has become important strategic goal. The following are recommendations derived from field studies in this context:

a) detail documentation of prominent georelief locations (Zhensikbayeva, 2018) using the tools of geoinformatics. 
b) development of sites with considerable geotourism values in terms of quality of geomorphosites.

c) permanent trekkers hut construction at suitable places on route with reference to carrying capacity analysis.

d) ensure community participation (Neto, 2003) at maximum extent to manage trekking and geotourism guiding on such sites.

e) sound disaster management plan to rescue the trekkers, if emergency arises.

The economy of Sikkim depends on trekkers' influx and their activities. Sikkim state is famous for mountain view of Himalaya and Alpine forest with Rhododendron species diversity. For such reasons there found large number of trekkers' influx in every year. The rapidly growths of trekkers' in the study area could be managed with the materialization of the recommendations put forwarded with divercification of their activities through geotourism promotion. Sustainable trekking strategies and techniques following the essential norms of geoconservation may lead to a healthy symbiosis of trekking and geotourism, essential for a backward area development.

\section{Acknowlegments}

The authors would like to express their gratitude to the members of Hi-Trek and Santipur Trekking Association especially Arup Acharya and Sougata Banarjee for extending active support in field survey and triangulation.

\section{REFERENCES}

Baxter, J., \& Eyles, J. (1997). Evaluating qualitative research in social geography: establishing 'rigour' in interview analysis. Royal Geographical Society, 22, p.505-525.

Bhutia, S. (2015). Sustainable Tourism Development In Darjeeling Hills of West Bengal, India: Issues \& Challenges. Global Journal of Human Science, 15 (3).

Cappucci, M., Pavliashvili, N., \& Zarrilli, L. (2015), New Trends in Mountain and Heritage Tourism: The Case of Upper Svaneti in the Context of Georgian Tourist Sector. GeoJournal of Tourism and Geosites, 1(15), p.67-80.

Cavuta, G., \& Matteo, D.D. (2016). Landscape Protection and Eco-development: The Case Study of Gargano National Park, Italy. GeoJournal of Tourism and Geosites, 1(17), p.95-111.

Chattaopadhyay, G., P. (2007). Deglaciation and hazard of glacial lake outburst in the Alpine regions: some observations around the glaciers on the southeast-facing of Kanchenjungha, Sikkim Himalaya. In Basu, S. R. and De, S.K. (Eds.). Issues in Geomorphology and Environment (p.79-9o). acb publications. Kolkata, India.

Chettri, N., Deb, D., C., Sharma, K., \& Jackson, R. (2005). The Relationship Between Bird Communities and Habitat. Mountain Research and Development, 25 (3), p.235-243.

Chettri, N., Sharma,E., \& Deb, D.C. (2001). Bird Community Structure along a Trekking Corridor of Sikkim Himalaya: A Conservation Prespective. Biological Conservation,102, p.1-16.

Dam, S. (2013). Issues of Sustainable Ecotourism Development in Sikkim: An Analysis. South Asian Journal of Tourism and Heritage,6 (2),p.32-48.

Datta, D., \& Banerji, S. (2015). Local Tourism invite in an Eastern Himalayan Village: Sustainable Ecotourism or Small-Scale Nature Exploration. Bulletin of Geography,Socio Economic Series,27, p. 33-49.

Forleo, M., B., Giannelli, A., Glaccio, V., Palmieri, N., \& Mastronardi, L. (2017). Geosites and Parks for the Sustainable Development of Inner Areas: The Matese Mountain (Italy). GeoJournal of Tourism and Geosites. 2 (20), p.231-242.

Gavrila, I., G., Man, T., \& Surdeanu, V. ( 2011). Geomorphological Heritage Assesment using GIS Analysis for Geotourism Development in Macin Mountains, Dobrogea, Romania. GeoJournal of Tourism and Geosites, 2 (8), p.198-205.

Gozner, M. (2014). Tourisitic Organization of the Trails and Belvedere Spots in the Albac- Arieseni Territorial System. GeoJournal of Tourism and Geosites, 2 (14), p.185-192.

Hakim, L., \& Soemarno, M. (2017). Biodiversity Conservation, Community Development and Geotourism Development in Bromo-Tengger-Semeru-Arjuno Biosphere Reserve, East Java. GeoJournal of Tourism and Geosites, 2 (20), p.220-230.

Hassan, Salah., S. (2000). Determinates of Market Competitiveness in an Environmentally Sustainable Tourism Industry. Journal of Travel Research, 38, p.239-245.

Irimus, I., A., Petrea, D., Vescan, I., Toma, C., B., \& Vieru, I. (2011). Vulnerability of Touristic Geomorphosites in Transylvanian Saliferous Areas (Romania). GeoJournal of Tourism and Geosites, 2 (8), p. 212-218. 
Joshi, R., \& Dhyani, P., P. (2009). Environmental Sustainability and Tourism implications of trend synergies of Tourism in Sikkim Himalaya. Current Science, 97 (1).

Kumara, S., Behera, M. D., \& Tewari, H., R. (2010), Identification of Potential Ecotourism sites in West District, Sikkim using Geospatial Tools. Tropical Ecology,51 (1), p.75-85.

Luitel, K., K., Shrestha, D., G., Sharma, N., P. \& Sharma, R., K. (2012). Impact on Climate Change on EastRatong Glacier in Rangit Basin, West Sikkim. In Arrawatia, M.L. and Tambe,S. (Eds). Climate Change in Sikkim: Patterns,Impacts and Intiatives(57-68). Information and public Relations Department. Government of Sikkim, India.

Maraszalek, L. ( 2018). Importance of Environmental Conditions for the Development of Tourism in the Drawsko Landscape Park (Poland). GeoJournal of Tourism and Geosites, 1 (21), p.39-48.

Miccadei, E., Sammarone, L., Plancentini,T., D’amico, D., \& Mancinelli, V. (2014). Geotourism in the Abruzzo, Lazio, and Molise National Park (Central Italy): The Example of Mount Gerceo and Chiarno Valley. GeoJournal of Tourism and Geosites,1 (13), p.38-51.

Nepal, S., K., \& Nepal, S., A. (2004). Visitor Impacts on Trails in the Sagarmatha (Mt. Everest) National Park, Nepal. Royal Swedish Academy of Sciences,33 (6), p.334-340.

Neto, F. (2003). A New approach to Sustainable Tourism Development: Moving beyond Environmental Protection. Natural Research Forum 27, p.212-222.

Priskin, J. (2001). Assesment of Natural Resources for Nature Based Tourism: The Case of the Central Coast Region of Western Australia. Tourism Management, 22,p.637-648.

Rai, S., C., Sharma, E., Lepcha, R., \& Sundriyal, R., C. (1998). Tourism Development in Sikkim. In S.C. Rai, R.C. Sundriyal and E. Sharma (eds): Sikkim Perspective for planning and Development, Sikkim Science Society and Bishen Sinngh and Mahendra Pal Singh, Deradun, p.709.

Rubita, I. (2012). Sustainability Issue in Tourism: A Case Study of Yaksum Village, Sikkim. AJTS,7 (2), p.117-129.

Serrano, E., \& Gonzalez Trueba, J., J. (2011). Environmental Education and Landscape Leisure, Geotourist Map and Geomorphosites in the Picos De Europa National Park. GeoJournal of Tourism and Geosites,2 (8), p.295-308.

Singh, K., K., Kumar, S., Rai, L., K., \& Krishna A., P. (2003). Rhododendron Conservation in the Sikkim Himalaya, Current Science,85(5),p.602-606.

Steynberg, L., \& Grundling, J., P (2005). Sustainability of Adventure Tourism: The Economic Highway, Sustain Development and Planning II, 2.

Strba, L. (2015). Identification and Evaluation of Geosites along Existing Tourist Trail as a Primary Step of Geotourism Development: Case Study from the Spis Region (Slovakia). GeoJournal of Tourism and Geosites, 2(16), p.127-141.

Subba, S., Lachungpa, D., Nepal, S., Subba, S., Tamang, M., \& Bhutia, D., C. (2016). Quantitative analysis of Vegetation Patterns and Plant Species Diversity in Different Forest Types at Yuksam- Dzonri- Goeche La sampling Path in Khangchendzonga Biosphere Reserve, West Sikkim, India, Journal of International Academic Research for Multidisciplinary,4 (9), p.203-219.

Thomas, B. (2016). Economic Impact of Ecotourism on Lives of Service Providers with Reference to Four Villages of Sikkim. Imperial Journal of Interdisciplinary Research,2 (10).

Zhensikbayeve, N., Z., Saparov, K., T., Chlachula, J., Yegorina, A., V., Uruzbayeva, N., A. \& Wendt, J., A. ( 2018). Natural Potential for Tourism Development in Southern Altai (Kazakhstan). GeoJournal of Tourism and Geosites, 1 (21), p.200-212.

*** Geological Survey of India (2012). Geology and Mineral Resources of the States of India. Miscellaneous Publication, 30 (XIX).

Submitted:

15.09.2018
Revised:

23.11.2018
Accepted and published online 26.11.2018 